\title{
Floods in Var, South Easthern France, January 2014 - Involvement of local and national actors in an experience feedback
}

\author{
Christophe ESPOSITO ${ }^{1, a}$, Anne-Marie FROMENTAL ${ }^{2, b}$, Mathieu ALQUIER ${ }^{2, \mathrm{c}}$, Isabelle ROUX ${ }^{2, \mathrm{~d}}$ \\ ${ }^{1}$ DIRMED/ Roadside Ingeenering Service de Marseille- 16 rue Bernard du Bois, 13001 Marseille, christophe.esposito@developpement- \\ durable.gouv.fr \\ ${ }^{2}$ Cerema Direction territoriale Méditerranée - CS 70499 - 13593 Aix-en-Provence Cedex 3 \\ ${ }^{b}$ anne-marie.fromental@cerema.fr ${ }^{c} \underline{\text { mathieu.alquier@cerema.fr }}{ }^{d}$ isabelle.roux@cerema.fr
}

\begin{abstract}
The feedback of January 2014 floods in Var is the object of a 3 parts report. The one at stake is dedicated to the event characterization. This work requires that State services, public administrative establishments, local and regional authorities and the main technical actors of the territory work together. The nature, intensity and return period of phenomena are defined and compared with past studies or past events. On the Argens river, January 2014 flood is not the reference event, the peak-discharge is lower than those observed during the 2010 and 2011 major events which were considered for the PPRI elaboration. For Gapeau and other coastal rivers, January 2014 event gets closer or exceeds the flows estimated for the PPRI reference event. In the end, recommendations for the capitalization of feedback elements for potential future floods are given.
\end{abstract}

\section{Context}

On January, 19, 2014, heavy rains caused severe flooding in the Var. The most affected areas were : Pierrefeu-du-Var and the coastal villages (Hyères, la Londe-des-Maures, Le Lavandou, Bormes-LesMimosas), the villages along the Argens river (from le Muy to Fréjus), around Le Luc en Provence village.

The Territorial Division for the Mediterranean Regions (Cerema DTerMed) has been requested by two state services (i) to draw up an experience feedback report over three topics: 1-event characterization 2-losses and damages 3-crisis management. This work has been carried out from January to July 2014, it required several follow-up meetings. The aim was to understand correctly the observed phenomena, thus to cope better with future (rainfall) events. The first topic deals with describing event and draw up a precise characterization of the phenomena (nature, intensity, return period,...) and compare it to current knowledge from studies or past events.
It required increased coordination with many organisms through the following actions:

- Analysis of aerial photographs taken by the IGN between 2014 January 21st and 24th

- Collection and compilation of High Water Marks (HWM)

- Georeferenced photo reports on the most affected areas

- Identification of vulnerability factors

- Comparison of the flood extent to the studies and hydraulic models available and to previous floods.

The characterization of the phenomena (coastal flood, river flood or pluvial flood) was drawn up by the Cerema on all the concerned rivers: Réal Martin, Gapeau, Pansard, Maravenne, Batailler, Roubaud excepted the Argens rivers and its tributaries studied by a private engineering company (Safege, 2014).

(i) The Directorate for the Environment, Development and Housing of Provence Alpes Cotes d'Azur region (DREAL PACA) and the Department Territorial Directorate for the sea of Var (DDTM 83)

\footnotetext{
${ }^{\text {a }}$ Corresponding author: christophe.esposito@developpement-durable.gouv.fr
} 


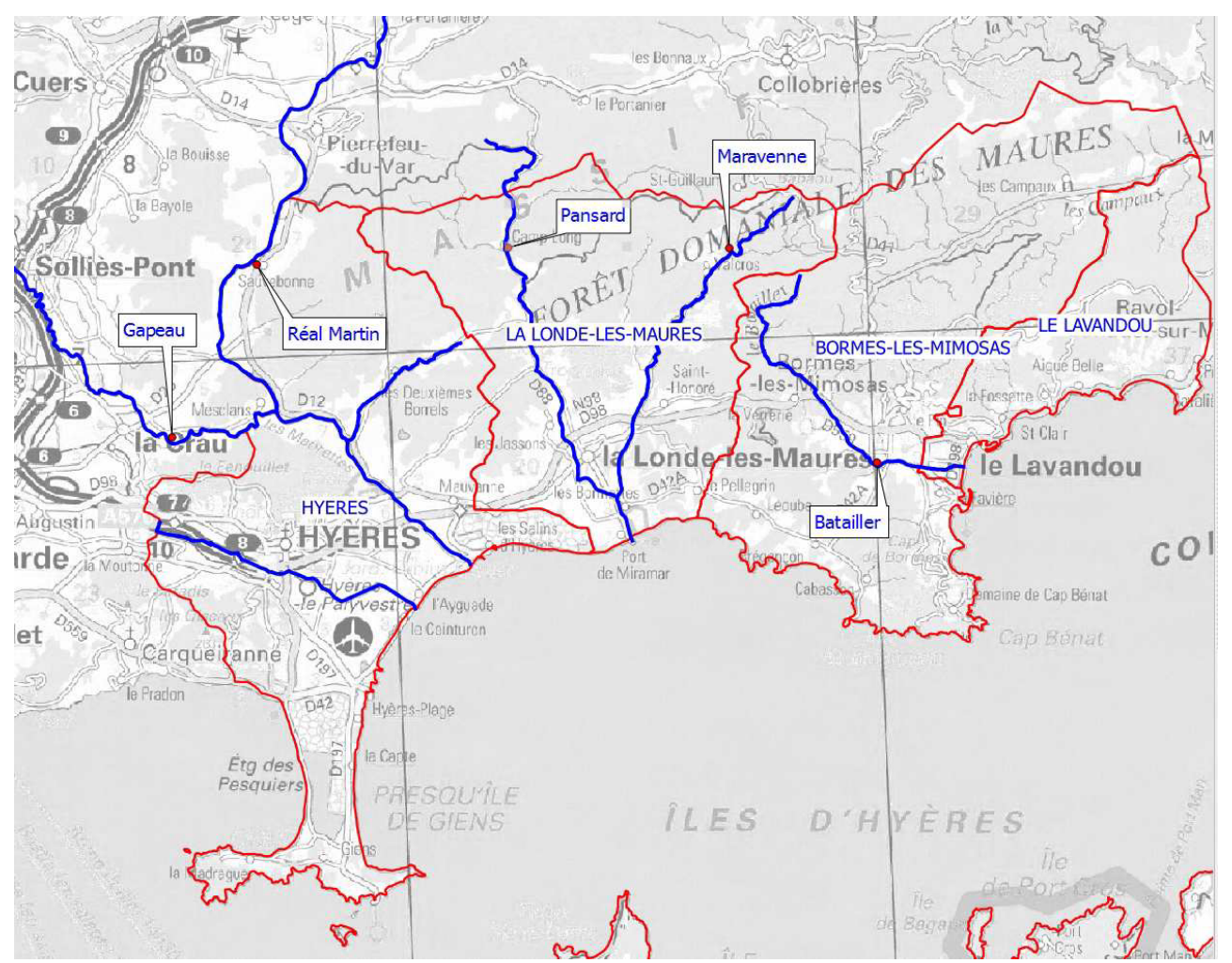

Figure 1. Location of the cities and the streams.

Municipalities borders

Streams

\section{Method}

\subsection{Aerial photographs}

An aerial photographs survey was launched the day after the flood. DREAL PACA decided to lead it in order to help defining the flood extent and localize the flood major damages and its indirect effects (e.g. landslides, bank erosion ...).

This aerial survey was carried out by the IGN (French National Geographical Institute), the results expected were:

- A fully ortho-rectified photographs in true colours (RGB) and in infra-red (IRD) with $10 \mathrm{~cm}$ resolution

- A post treated topographic dataset using LIDAR (Light Ranging and Detection) technology with $5 \mathrm{~m}$ resolution

For the coastal streams, on the request of State services, two sectors were covered :

-FUVAR survey covering Gapeau, Roubaud, Réal Martin, Maravenne and Batailler

-FUARGENS survey covering Argens and its tributaries.

The air flights occurred on 21st January (for the FUVAR survey) and on 24th January (for FUARGENS survey).

\subsection{Field visit}

In the aftermath of the flood, several teams were constituted with agents from Cerema, state services and municipalities who went to the field.

Their aim was to identify the most affected areas and to prepare a preliminary diagnosis of the situation in term of both hydraulic phenomenon and damages.

The 21st january field visit went off with State and municipalities representatives in 8 communes (i). More detailed visits took places on 23rd and 24th January in 4 communes (ii). A formal briefing report was written for each visit.

Going on the field in very next days after the flood allows to get early observations and to prepare a global field visit providing a relevant overall vision. Those early visits should be organized jointly with local stakeholders, especially communal technical services. In order to allow discussion and dialogue with the local actors and inhabitants, the time required should not be underestimated. It is worth planning further field visits, focused on specific themes or areas and based on experience and analysis from the first field visits.

(i) Le Luc, Flassans-sur-Issole, Les Arcs, La Londe-les-Maures, Puget-sur-Argens, Roquebrune-sur-Argens, Fréjus et le Muy

(ii) La Londe-les-Maures, Bormes-les-Mimosas, Pierrefeu and Hyères 


\subsection{High Water Marks collection}

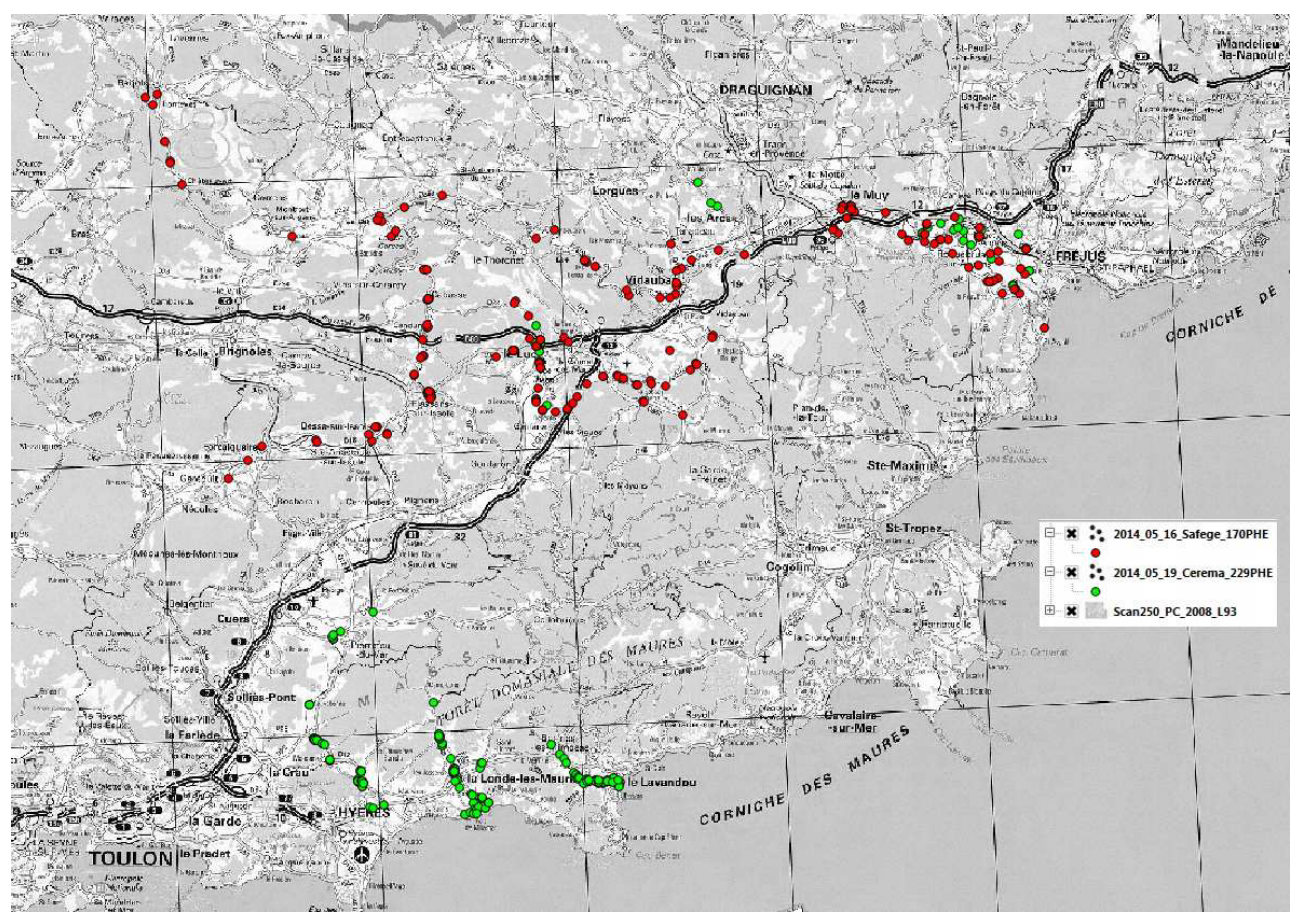

Figure 2. High Water Marks locations

\section{HWM SAFEGE \\ HWM Cerema}

The purpose of collecting High Water Marks is to help mapping flood inundation areas and identifying the flood flows and its frequency.

Before the first field visit, Sate services had contacted some local actors in order to ensure that the High Water Mark collection operated by various organisms concerned by the post-event management (i) would not be redundant. Because of the multiplicity of heterogeneous High Water Mark collections, a key issue was to coordinate the collection and gather data.

All collecting organisms produced data sheet related to each HWM. In total, 398 HWM with their data sheet were produced. Among those 398 HWM, 250 were leveled by a surveyor (geo location $\mathrm{X}, \mathrm{Y}$ and $\mathrm{Z}$ of the water levels). Figure 2 shows the set of the 398 HWM collected on the studied area: 168 in the Argens watershed, 230 in the valley of others coastal streams. Cerema compiled all the HWM data in a regional database owned by DREAL PACA.

This database will be incorporated into the future national HWM database being set up by the Central Service of Hydrometeorology and support for the flood forecasting (SCHAPI). Thus, a simple and interoperable format (Excel) has been chosen with clearly identified database fields.

(i) List of the concerned organisms:

$\checkmark$ State services: DREAL PACA, DDTM83, flood forecasting service SPC Med Est

$\checkmark$ Territorial authorities: County Council of the Var, the regional network for the managers of

\author{
the aquatic environment RRGMA, and \\ Municipalities \\ $\checkmark \quad$ A private engineering office: Safege \\ $\checkmark$ A public body: Cerema
}

\subsection{Flood Map}

\subsubsection{Flood maps from the municipalities}

Cerema gathered some local flood maps (in GIS or PDF format) drawn by the municipalities, but the methods used were not clearly specified. Those flood maps were drawn very quickly after the flood with unchecked and unconsolidated data. The municipalities of La Londe-les-Maures, Hyères and Bormes-lesMimosas provided us with a flood map. We compared the flood inundation from the municipalities and with the HWM collected during the field visits. Some discrepancies were highlighted: for example for the stream of Batailler in Bormes-les-Mimosas (Figure 3).

On Figure 3, the two HWM named "BAT_08', and "BAT_45" are out of the flood inundation mapped by the municipality (green border). That border isn't consistent with field observations that provide other border for the flood inundation (turquoise border). That why Cerema produced a "synthetized" flood map. 


\subsubsection{Synthetised flood map}

To produce a synthetised "by expert opinion" flood map, the following data were cross-checked:

- Flood maps from the municipalities,

- Data sheets of HWM,

- Georeferenced arial photographies,

- Digital Terrain Model Lidar resolution $1 \mathrm{~m}$ from RGEALTI may 2013 IGN,

- Digital Terrain Model 5m made from the IGN aerial survey on January 21, 2014.
As the result we draw up the interpreted borders of the flood extension. Each border has been qualified with an interpretation's grade:

1. High reliability;

2. Medium reliability ;

3. Low reliability.

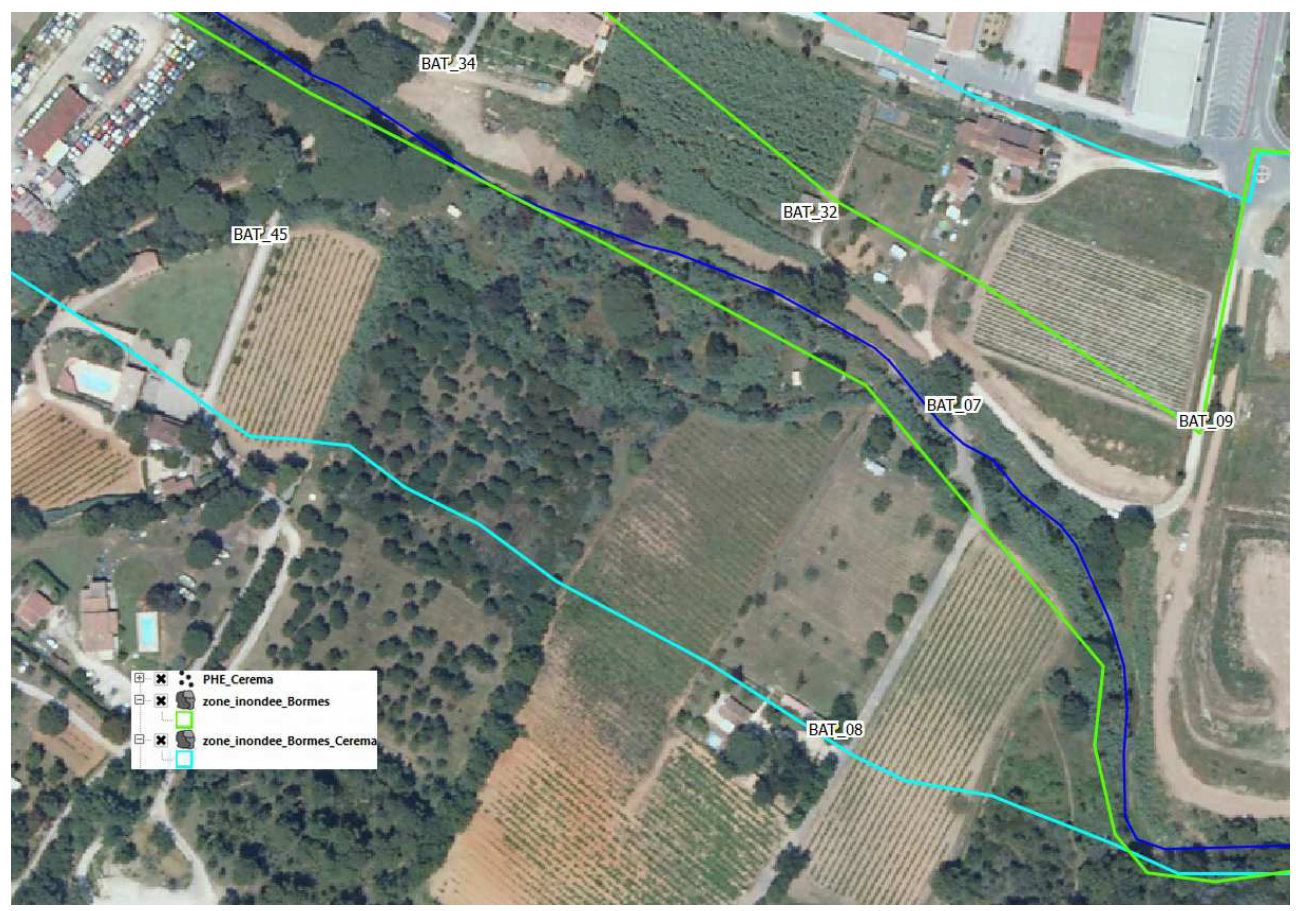

Figure 3. Discrepancies between HWM and flood map from the municipality.

$\begin{array}{ll} & \text { Stream } \\ & \text { Flood limit for the Municipality } \\ & \text { Flood limit for Cerema } \\ \text { BAT_XX } & \text { HWM }\end{array}$

\subsection{Hydrologic characterization}

From January $16^{\text {th }}$ to $19^{\text {th }}$, four days of heavy rain affected much of south-eastern France, especially Var and Alpes Maritimes.

According to Meteo France, the four-day rainfalls were equivalent of one or two months rainfall. This is an important but not extreme situation. Near La Londes-lesMaures village in Var department, between 200 and 250 $\mathrm{mm}$ fell in four days, representing only half the one day rainfall of June, 15, 2010, in Var.

It should be pointed out that the heaviest rain occurred on Januray $19^{\text {th }}$, following three other rainy days. The already saturated soils worsened the impact of the latest rainfall.

Several streams overflowed: Argens river, Gapeau (flood due to his eastern tributary, Réal Martin) and coastal stream between La Londe-les-Maures (Maravenne with his affluent Pansard) and Le Lavandou (Batailler).

\subsection{Flood risk area VS flooded area}

\subsubsection{Atlas of Flood-prone Areas (AZI)}

The AZI provides documentation about the exposure to the risk, according to the French interministerial circular (Public Works, Environment) of January, 24, 1994, on flood prevention and flood-prone areas management. The flooded area is entirely included in the AZI.

\subsubsection{Plans for Flood Risk Prevention (PPRi)}

PPRi are established by the State. They define risk areas and a set of regulations (prohibited or constructible zones with some restrictions). The PPRi risks areas were compared to the flooded area of January 2014.

- For the Argens watershed, the flooded area doesn't significantly exceed the risk limits of the PPRI. 
- For the Gapeau in Hyères city, the flooded zone is far beyond the PPRi limits for the left bank of the Gapeau downstream of the Real Martin. Indeed, the PPRi map (HGM Environnement, 2001), only considered the maintream Gapeau whereas little tributaries (les Borrels, Sainte Eulalie...) overflowed onto the plain.

- For the villages of Bormes-les-Mimosas and Le Lavandou (Batailler river), the flooded area locally exceeds the limits of the PPRi for Batailler river . Most of the flooded area is included in the PPRi limits but in some areas the water levels reached by the floods are higher than those calculated in the lockers of the PPRi model.

- For Londe-les-Maures village, all the HMW collected in Pansard and Maravenne watershed exceed the water levels of the PPRi.

\subsubsection{Maps from the Flood Directive}

This European directive (2007/60/CE), on the assessment and management of flood risks, among other things, requires member states to identify the river basins at risk of flooding and to establish flood hazard maps associated with different flood scenarios.

Two areas of high flood risk (Territoires à Risques Importants d'inondation or TRI) identified by the directive are concerned by the January 2014 flood.

For the TRI "Est Var', in Argens valley, the frequent scenario of the flood hazard map is included in the flooded area. Therefore the flood can be considered more as a rare phenomenon than a frequent one.

The flooded area is close or exceeds the flood extent for the medium and extreme event scenarios downstream from the confluence of Nartuby and Argens. But the water levels of the HWM are lower than those modeled in the scenarios of the TRI.

For the TRI "Toulon', in Gapeau valley, the flood hazard is only mapped downstream of its confluence with Real Martin. Flooded area often exceeds the limits of the frequent scenario. The medium scenario contains some inconsistencies and cannot be properly compared to flooded area. The limits of the flooded area are close to those of the extreme scenario, but the water levels of the extreme scenario are much higher than the HWM collected in the area.

\subsubsection{Flooded zone of June 2010}

The exceptional rainfall of 15 June 2010 in Var leaded to generalized flooding in Dracenie region. Near Lorgues a maximum of $456 \mathrm{~mm}$ rainfall was measured in less than 24 hours.

Many fields' surveys were launched after the flood. The flooded area was mapped and 1187 HWM were collected. We compared June 2010 HWM with those collected after January 2014 flood. Only 26 HWM were collected at the same location. For those HWM, June 2010 event was always stronger than January 2014 one. In 2014, only in Le Muy municipality, 3 HWM went above June 2010 ones but those discrepancies were due to obstacles (cars disturbing water flow).

\section{Conclusions}

This abstract on "event characterization" of the January 2014 flood that hit Var highlights the actor complementarity needed to carry out this action.

These results, obtained thanks to the skills and data of all local actors, enable to characterize accurately the phenomena at stake (nature, intensity, return period) and to compare them with current knowledge coming from previous event or studies.

Lastly, we can come up with recommendations concerning feedback element gathering and build up feedback code of practices at regional level for possible future flood.

\section{References}

1. Cerema, Direction territoriale Méditerranée (2014). Retour d'Expérience des intempéries sur le département du Var du 19 janvier 2014, Caractérisation hydraulique de l'événement, octobre 2014 - rapport d'étude, $226 \mathrm{p}$.

2. CETE Méditerranée, Esposito, C. (2012). Crue de juin 2010 -Comparaison des limites des zones inondables connues avec les limites des zones inondées - rapport d'étude, $129 \mathrm{p}$.

3. Esposito, C., Chave, S., Delgado, J.-L. (2004). Retour d'expérience : les crues de septembre 2002 dans le Gard et les départements limitrophes DGUHC, 62p.

4. HGM Environnement (2001). Étude de l'aléa inondation du Gapeau dans la plaine de Hyères-lesPalmiers - Direction Départementale du Var - 22 p.

5. IRSTEA, Arnaud, P., Lavabre, J. (2010). Guide méthodologique sur l'approche SHYPRE. Partie 1 : analyse du risque pluvial. Édition QUAE, $125 \mathrm{p}$.

6. Safege (2014). Analyse hydrologique et hydraulique de la crue du bassin versant de l'Argens des 18 et 19 janvier 2014 - Retour d'expérience de l'événement Action $\mathrm{n}^{\circ} 10 \mathrm{du}$ PAPI d'intention - Argens et affluents, rapport d'étude, $158 \mathrm{p}$.

7. SIEE (1996). Étude des zones inondables des rivières de La Vieille et du Batailler - Première phase : État zéro des rivières - Syndicat intercommunal pour la prévention contre les inondations des Communes de Bormes et du Lavandou, $64 \mathrm{p}$. 